\title{
Balance Sheet versus Earnings Conservatism in Europe
}

\author{
JUAN MANUEL GARCÍA LARA* AND ARACELI MORA** \\ ${ }^{*}$ Lancaster University, UK \\ ** Universidad de Valencia, Spain
}

\begin{abstract}
In this study we extend prior research on the international analysis of accounting conservatism (Joos and Lang, 1994; Ball et al., 2000; Giner and Rees, 2001), by examining the level of accounting conservatism across eight European countries (United Kingdom, Germany, France, Switzerland, the Netherlands, Italy, Spain and Belgium), and assessing the statistical significance of the differences among them. The definitions of conservatism that we use are, on the one hand, the Feltham and Ohlson (1995) definition, which implies a persistent understatement of book value of shareholders' equity (balance sheet conservatism). On the other hand, we use the one proposed by Basu (1997), that is, a timelier recognition of bad news in earnings relative to good news (earnings conservatism). We also address the possible scale problems of the models used to measure balance sheet conservatism. Finally, we check whether our comparative results could be influenced by a different sample composition in each country. Our results show that there are both balance sheet and earnings conservatism practices in all countries under study. In addition, while continental countries show larger balance sheet conservatism, differences in earnings conservative practices between countries are not that pronounced, although they tend to be larger in the UK. We also find that the existence of balance sheet conservative practices is associated with reduced levels of earnings conservatism, which is consistent with the results in Pope and Walker (2003).
\end{abstract}

\section{Introduction}

From a historical point of view, Watts (1993) points out that the role of conservatism has been related to contracts splitting the firm's returns among the

Correspondence Addresses: Juan Manuel García Lara, Lancaster University, Management School, Department of Accounting and Finance, Bailrigg, Lancaster LA1 4YX, UK. Araceli Mora, Facultad de Economía, Departamento de Contabilidad, Avenida de los Naranjos s/n, 46022, Valencia, Spain. E mails: j.garcialara@lancaster.ac.uk and Araceli.Mora@uv.es 
various claimants. In liquidations and bankruptcies, accountants recognized all possible losses before making a distribution. The objective is to ensure that there is not a distribution to someone when there is the possibility that someone else with a prior contractual claim will not be paid. Accountants could have used conservatism to achieve a similar end in continuing firms, in particular to assure debtholders of their primacy over the shareholders.

From an institutional point of view we find similar definitions of conservatism. For example, in the APB 4 (1970) it was stated that, 'Historically, managers, investors, and accountants have generally preferred possible errors in measurement to be in the direction of understatement of net income and net assets. This had led to the convention of conservatism' (para. 171). The FASB also gave its 'official' definition of conservatism in its Statement of Financial Accounting Concepts 2 (1980), where conservatism was described as 'a prudent reaction to uncertainty to try to ensure that uncertainty and risks inherent in business situations are adequately considered'. Later on in the SFAC 2 it can be interpreted that this reaction to adequately consider risk is the choice of the lower estimate of future cash flows when two estimates are equally likely. ${ }^{1}$

In a similar way, Smith and Skousen (1987) describe conservatism as the rule whereby 'when there is a genuine doubt concerning which of two or more reporting alternatives should be selected, the alternative with the least favourable effect upon owners' equity should be chosen'.

Focusing more on valuation of accounting numbers, Belkaoui (1985), claims that the term 'accounting conservatism' implies that 'preferably the lowest values of assets and revenues and the highest values of liabilities and expenses have to be reported'.

This traditional definition of conservatism implies a consistent understatement of both book value of shareholders' equity (which should imply a market-to-book ratio consistently greater than one) and earnings. Nevertheless, and as several authors point out, while it is possible to undervalue shareholders' equity consistently (due to historical cost accounting, to the non-recognition of certain intangible assets, etc.), it is not always possible to do so with earnings, since differences are temporary and they will unravel. ${ }^{2}$ Due to the accrual principle, gains (losses) that are not recognized now will be recognized later on. Thus, in the long run, accounting earnings will tend to economic earnings.

One different definition of conservatism that we find in the literature is the one in Basu (1997). Basu interprets conservatism as capturing accountants' tendency to require a higher degree of verification for recognizing good news than bad news in earnings. Basu's definition focuses on the protection of shareholders, who demand to be informed in a timely way through financial statements in order to be able to make their investment decisions, and this demand for timely information will be even more important in the case of bad news. He also argues, following Smith (1979), that debtholders and other creditors demand timely information about bad news because the option value of their claims is more sensitive to a 
decline than an increase in firm value. Ball et al. (2000) refer to this definition as 'income (or earnings) conservatism', ${ }^{3}$ to differentiate it from the more traditional definition (understatement of shareholders' equity) that they call 'balance sheet conservatism'. ${ }^{4}$ Watts (2002) provides insights into the prior literature on earnings and balance sheet conservatism, and describes how conservatism affects different aspects of accounting.

In this study, we replicate and extend previous comparative studies on earnings conservatism (Ball et al., 2000; Giner and Rees, 2001) and on balance sheet conservatism (Joos and Lang, 1994). We compare the level of these two types of accounting conservatism across eight European countries (United Kingdom, Germany, France, Switzerland, the Netherlands, Italy, Spain and Belgium) using both concepts (earnings and balance sheet conservatism), and assessing the statistical significance of the differences among them. We expect that in the so-called common-law-based countries or Anglo-Saxon countries (United Kingdom), the degree of balance sheet conservatism will be less pronounced than in the so-called code-law-based countries or 'continental' countries (Germany is the most extreme example). ${ }^{5}$ Contrarily, we expect 'continental' countries to show smaller earnings conservatism than the United Kingdom.

As an additional methodological issue, we try to cope with the possible scale problems that according to several authors affect the results of the models used to measure balance sheet conservatism. Finally, we check whether our comparative results could be influenced by a different sample composition in each country, undertaking a sensitivity analysis. Through this sensitivity analysis we will also be able to analyse the interaction between balance sheet and earnings conservatism. ${ }^{6}$ Following Pope and Walker (2003), who analyse the interaction between the market-to-book ratio and earnings conservatism in the United States, we expect balance sheet conservative practices to reduce the level of earnings conservatism.

We find that there exist both balance sheet and earnings conservatism practices in all countries under study, that there are significant differences in conservatism between countries, and that balance sheet and earnings conservatism are negatively correlated.

Our results have implications for accounting standard setting, especially in a moment in which the European Union is trying to set up a new single securities market in Europe. Conservatism can be one of the most important sources of disparity in financial information across European countries. The analysis of the situation prior to the implementation of the new IASB (International Accounting Standards Board) standards, with which all listed European Union firms will be obliged to prepare their consolidated accounts at the latest from 2005 onwards, is of crucial importance to any subsequent assessment of whether the usage of a common set of standards has been of any help to reduce the differences between the countries and if they can contribute to the establishment of an efficient single securities market in Europe. 


\section{Previous Evidence}

\section{Balance Sheet Conservatism}

The definition of balance sheet conservatism that we use in our study is the one stated by Feltham and Ohlson (1995), who define conservatism as the existence of a persistent understatement of the book value figure with respect to market's valuation of the firm. This implies that the market-to-book ratio will be greater than one. The effects of this notion of accounting conservatism are analytically described by Feltham and Ohlson (1995), Beaver and Ryan (2000) and Zhang (2000).

Following Zhang (2000), we assume that there exists balance sheet conservatism if

$$
\lim _{\tau \rightarrow \infty} E\left[o a_{t+\tau}\right] / E\left[V_{t+\tau}\right]<1
$$

where $o a$ is operating assets and $V$ is the market value of operating assets. Zhang (2000) describes conservatism in terms of operating assets (as in Feltham and Ohlson, 1995), assuming that 'perfect' or 'unbiased' accounting holds for financial assets and liabilities and assuming there are perfect markets for them. However, the relation continues to hold if we use the total book value of assets and the market value of the firm (market capitalization).

This understatement of shareholders' equity with respect to market's valuation of the firm is attributable (among other factors) to the usage of historical cost accounting, to the non-recognition of certain intangible assets or, as Smith and Watts (1992) point out, to the existence of a favourable investment opportunity set, that is, to growth options. Holthausen and Watts (2001) also point to the existence of rents or synergies between assets as possible explanations.

Few studies have tested until now the existence of this type of accounting conservatism. Joos and Lang (1994) analyse the book-to-market ratio in Germany, France and the UK, for the period 1982 90, and their results show that it is consistently smaller than one. They also find that Germany shows statistically significant larger balance sheet conservatism than France and the UK. Joos (1997) uses a simplification of Bernard's (1995) empirical development of the theoretical models by Ohlson (1995) and Feltham and Ohlson (1995), obtaining similar results to those in Joos and Lang (1994). They show that the book value multiple, on a regression of price on earnings and book value of shareholders' equity, is greater in Germany and France than in the UK. They explain this difference on the book value multiple arguing that the accounting system in continental countries, where financial institutions are the main providers of finance, tend to understate shareholders' equity to assess the borrowing capacity of the firm from a pessimistic perspective. Focusing on the United States, Stober (1996) and Givoly and Hayn (2000) analyse the evolution of the market-to-book ratio, which they use as a proxy for balance sheet conservatism. Givoly and Hayn (2000) find that there exists balance sheet conservatism, that is, that the market-to-book ratio is always greater than one, and that the level of balance sheet conservatism has increased consistently during the last three decades. Finally, Ahmed 
et al. (2002), using the model proposed in Beaver and Ryan (2000), find that there is a trade-off between balance sheet conservatism and the cost of debt.

\section{Earnings Conservatism}

When we use the definition of conservatism by Basu (1997), we are assuming that conservatism is an issue of the timing and sequencing of gains and losses relative to the associated cash flows.

Basu (1997), using a reverse regression, studies for the first time the asymmetry and timeliness in incorporating good and bad news in accounting earnings. He argues that earnings are timelier or more concurrently sensitive in reflecting publicly available bad news than good news. ${ }^{7}$ To test this prediction of asymmetric timeliness, he uses negative and positive unexpected annual stock returns as a proxy for bad and good news.

Basu (1997) finds that bad news is recognized faster in earnings than good news. ${ }^{8}$ He attributes the asymmetry between good and bad news recognition in earnings to the legal liability exposure faced by auditors and managers for tardy disclosure of bad news. Conservatism reduces auditors' and managers' liability exposure and they are thus expected to have increased the asymmetric timeliness of earnings in response to increases in their legal liability exposure. ${ }^{9}$ Holthausen and Watts (2001) also find that earnings conservatism is positively related to the evolution of litigation risk.

Ball et al. (2000) extend the Basu (1997) analysis to seven international GAAP regimes (Australia, Canada, USA, UK, France, Germany and Japan). They document substantial variation in the degree of asymmetric timeliness across regimes, and attribute this variation to differences in the legal and institutional environments for financial reporting in the countries examined. ${ }^{10}$

Asymmetry in earnings response to news is observed to some extent in all countries in their sample. According to them, the asymmetric accounting treatment of good and bad news is further accentuated in the US by two institutional variables: the tighter regulation of the accounting profession by political and administrative functions that are keen to avoid crises, and the higher expected cost to US accountants and their client firms of stockholder and bondholder litigation, which creates further incentives for the prompt disclosure of bad news. Their results include the extreme conservatism of the US, Canada and Australia relative to continental European countries and Japan, while the UK is in an intermediate position.

Pope and Walker (1999) argue that the measured level of earnings conservatism depends on the definition of earnings, that is, earnings before or after extraordinary items. They examine both, for the US and the UK, and their results suggest that the United Kingdom is at least as earnings conservative as the United States, but news is classified differently in the income statement in the two countries. Their results are consistent with those in Ball et al. (2000) when they use earnings before extraordinary items, but when they use earnings after extraordinary items the degree of earnings conservatism is fairly similar in both countries. 
Other studies, like Givoly and Hayn (2000) and Holthausen and Watts (2001), extend Basu's analysis, confirming his results and inferences, and additionally examine the evolution of earnings conservatism in time, focusing on the United States. Givoly and Hayn (2000), show that the degree of earnings conservatism has consistently increased from the 1950s until 1998. Results in Holthausen and Watts (2001) show that the level of earnings conservatism is linked to the evolution of litigation risk faced by managers and auditors. They examine the period 192795 finding that in periods of high litigation risk, earnings conservatism increases.

Focusing on an international context, we can find evidence of the existence of earnings conservatism in Europe in Giner and Rees (2001), and in Asia in Ball et al. (2003). Giner and Rees (2001) analyse the UK, France and Germany, and their results suggest that the differences between those three countries are not as pronounced as in Ball et al. (2000), continuing a decreasing trend noted in Ball et al. (2000).

There is also an increasing number of papers that analyse different aspects regarding earnings conservatism, showing the increasing importance of this stream of research. ${ }^{11}$

\section{Hypotheses Development}

The aim of our empirical study is to provide evidence about whether there are differences in the level of both balance sheet and earnings conservatism between European countries, considering a larger and at the same time more homogeneous sample of countries (similar culture and macroeconomic environment) than in previous studies. Besides, and extending the US study in Pope and Walker (2003), we analyse the interaction between both types of conservatism in a European context. We test the following hypotheses:

\section{Hypothesis 1: All countries in our sample show balance sheet conservatism.}

We expect the accounting regimes in today's Western Europe to be leading to the existence of balance sheet conservatism practices, that is, to a persistent understatement of shareholders' equity. ${ }^{12}$ Lenders are interested in the likelihood that the firm will have enough assets to cover their loans. These lenders, if represented in the board of directors, as it is usual in most continental European firms, influence managers' decisions about asset valuation, making accounting more conservative. Also, they have the power to influence regulators. Losses from overvalued assets are more observable and usable in the political process than gains from undervalued assets. This provides incentives for regulators and standard setters to be conservative (see Watts, 2002).

Hypothesis 2: Code-law-based countries will show larger balance sheet conservatism than common-law-based countries. 
Continental countries accounting regulation has been developed to protect lenders' interests, since the main providers of capital are financial institutions. Code-law-based countries will show larger balance sheet conservatism more pronounced understatement of shareholders' equity than common-law-based countries, where firms' ownership is spread over a wide number of shareholders. In continental or code-law-based countries, financial institutions have the power to influence accounting regulators and direct the boards of directors to understate shareholders' equity. Financial institutions demand reduced values of shareholders' equity to be certain that, in case the firm has any kind of financial distress, they will recover their investment in the firm through the liquidation of assets.

\section{Hypothesis 3: All countries in our sample show earnings conservatism.}

We expect to find earnings conservatism practices in every country under study. Namely, in all countries, bad news is reflected in earnings on a timelier basis than good news, due to accountants' tendency to require a higher degree of verification for recognizing good news than bad news in financial statements.

\section{Hypothesis 4: Common-law countries' accounting earnings are more conservative than code-law countries'.}

We expect the United Kingdom (common-law-based country) to be significantly more earnings conservative than code-law-based or continental countries.

Ball et al. (2000) argue that the larger litigation risk faced by managers and auditors in common-law-based countries will make the asymmetric timeliness of earnings (bad news recognized on a timelier basis) more pronounced in those countries as an answer to an external demand for conservative measures. They also explain that in code-law-based countries managers try to reduce volatility in accounting income through accounting methods that smooth earnings over time, at the expense of earnings timeliness (see also Leuz et al., 2003).

At the same time, Pope and Walker (2003) explain that balance sheet conservatism reduces the measures of earnings conservatism. Accounting earnings will not capture news about an unrecognized asset. We expect, following the idea in Pope and Walker (2003), that the differences in earnings conservatism between the UK and continental countries are driven to some extent by balance sheet conservatism (greater in continental countries, reducing the measures of earnings conservatism more noticeably). As balance sheet conservatism decreases, differences between the UK and continental countries should disappear.

These arguments (litigation risk, income smoothing and balance sheet conservatism) explain the differential effect of earnings conservatism and our hypothesis of larger earnings conservatism (timelier recognition of bad news in earnings) in common-law-based countries. 


\section{Sample Selection and Research Design}

\section{The Sample}

To test our hypotheses we work with all available observations in the Extel Company Analysis database, up to May 2000, for eight European countries: the United Kingdom, Germany, France, Switzerland, the Netherlands, Italy, Spain and Belgium.

Using only Western European countries we can assume that the macroeconomic setting is similar throughout the sample (European Union countries have been harmonizing the inflation rate, public debt, deficit spending and interest rate since 1992). We can also assume that cultural differences are not as pronounced in Western Europe as they are between countries in previous studies, like in Ball et al. (2000). Also, political risk is similar in European countries, and most of them (France, Germany, the Netherlands, Italy and Spain in our sample) have adopted the euro as their single currency. However, they still differ in the development of financial markets and in the main providers of capital funds. These differences are also reflected in the accounting regimes.

We exclude financial firms from the analysis and delete from the sample all observations with missing values for any of the variables used. We only work with firms with accounting period length between 335 and 395 days. We also exclude the two extreme percentiles of each variable by country. ${ }^{13}$

Our final sample consists of 20,583 firm-year observations, for the period 19872000 to analyse balance sheet conservatism, and 12,306 firm-year observations for the period 19882000 to analyse earnings conservatism. Note that the difference in the sample size from balance sheet to earnings conservatism is mainly attributable to the need for at least two consecutive firm-year observations to calculate returns and also to the fact that we exclude all firms with missing values for the price adjustment factor variable, which we need to adjust prices for stock splits, new equity issues, etc.

In Table 1, which contains the descriptive statistics for the variables that we use for balance sheet conservatism, we can see that the mean, maximum and minimum values for share price in all countries are greater than the same values for book value of shareholders' equity per share. This is already providing evidence of the existence of balance sheet conservatism in all countries in our sample. Our sample size ranges from 10,024 firm-year observations for the United Kingdom, to 577 for Belgium. When we consider continental countries as a group, the sample for continental countries consists of 7,966 observations. ${ }^{14}$

Table 2 contains sample descriptive statistics for earnings conservatism. Consistent with previous research, as well as with the existence of asymmetry in news recognition in earnings, net income is negatively skewed (all medians exceed means), and exactly the opposite occurs with returns. Also, the standard deviation of net income is always smaller than the standard deviation of returns, consistent with the Ball et al. (2000) argument that net income is a function of past and present returns. In this case, our sample size ranges from 6,285 firm-year observations for 
Table 1. Descriptive statistics. Balance sheet conservatism

\begin{tabular}{|c|c|c|c|c|c|c|c|c|c|}
\hline & $B V$ & $N I$ & Sh. price & $B V$ & $N I$ & Sh. price & $B V$ & $N I$ & Sh. price \\
\hline & \multicolumn{3}{|c|}{ United Kingdom } & \multicolumn{3}{|c|}{ Germany } & \multicolumn{3}{|c|}{ France } \\
\hline Mean & 1.65 & 0.20 & 3.24 & 86.58 & 6.29 & 176.76 & 55.24 & 4.99 & 87.68 \\
\hline Maximum & 13.54 & 1.71 & 23.26 & 466.90 & 72.17 & $1,022.58$ & 410.44 & 57.25 & 719.90 \\
\hline Minimum & 0.29 & 0.85 & 0.03 & 0.03 & 59.77 & 7.23 & 0.68 & 21.03 & 2.09 \\
\hline Std dev. & 1.82 & 0.29 & 3.33 & 69.13 & 12.73 & 146.29 & 62.20 & 8.57 & 104.03 \\
\hline \multirow[t]{2}{*}{ Observations } & & & 10,024 & & & 2,743 & & & 2,976 \\
\hline & \multicolumn{3}{|c|}{ Switzerland } & \multicolumn{3}{|c|}{ Netherlands } & \multicolumn{3}{|c|}{ Italy } \\
\hline Mean & 629.63 & 49.58 & 851.37 & 27.33 & 3.58 & 43.52 & 2.55 & 0.19 & 3.22 \\
\hline Maximum & $6,503.87$ & 660.23 & $12,490.23$ & 353.24 & 65.32 & 794.12 & 17.96 & 1.58 & 26.49 \\
\hline Minimum & 2.66 & 163.97 & 10.86 & 0.45 & 12.00 & 1.67 & 0.04 & 0.92 & 0.12 \\
\hline Std dev. & 841.82 & 83.61 & $1,231.86$ & 38.34 & 5.95 & 64.78 & 2.34 & 0.29 & 3.38 \\
\hline \multirow[t]{2}{*}{ Observations } & & & 1,428 & & & 1,165 & & & 937 \\
\hline & \multicolumn{3}{|c|}{ Spain } & \multicolumn{3}{|c|}{ Belgium } & \multicolumn{3}{|c|}{ Total } \\
\hline Mean & 13.73 & 1.35 & 21.87 & 144.77 & 14.91 & 197.01 & 70.22 & 5.77 & 105.77 \\
\hline Maximum & 61.59 & 8.86 & 108.18 & $2,389.13$ & 469.08 & $2,974.72$ & $6,503.87$ & 660.23 & $12,490.23$ \\
\hline Minimum & 0.11 & 5.60 & 0.29 & 0.79 & 35.07 & 6.72 & 0.79 & 163.97 & 0.03 \\
\hline Std dev. & 10.91 & 1.84 & 20.85 & 250.76 & 38.30 & 294.18 & 277.18 & 26.71 & 397.36 \\
\hline Observations & & & 733 & & & 577 & & & 20,583 \\
\hline
\end{tabular}

$B V$ : Book value of shareholders' equity per share in euros; NI: Net income after extraordinary items per share in euros; Sh. price: Market share price in euros. 
Table 2. Descriptive statistics. Earnings conservatism

\begin{tabular}{|c|c|c|c|c|c|c|c|c|c|c|}
\hline & \multicolumn{2}{|c|}{ United Kingdom } & \multicolumn{2}{|c|}{ Germany } & \multicolumn{2}{|c|}{ France } & \multicolumn{2}{|c|}{ Switzerland } & & \\
\hline & $X$ & $R$ & $X$ & $R$ & $X$ & $R$ & $X$ & $R$ & & \\
\hline Median & 0.070 & 0.034 & 0.039 & 0.027 & 0.062 & 0.047 & 0.063 & 0.001 & & \\
\hline Mean & 0.046 & 0.078 & 0.031 & 0.091 & 0.049 & 0.123 & 0.040 & 0.113 & & \\
\hline Maximum & 0.380 & 1.608 & 0.383 & 1.644 & 0.508 & 1.975 & 0.668 & 4.672 & & \\
\hline Minimum & 0.895 & 0.699 & 0.501 & 0.554 & 0.764 & 0.670 & 2.164 & 0.769 & & \\
\hline Std dev. & 0.127 & 0.386 & 0.096 & 0.333 & 0.128 & 0.428 & 0.192 & 0.566 & & \\
\hline \multirow[t]{3}{*}{ Observations } & \multicolumn{2}{|c|}{6,285} & \multicolumn{2}{|c|}{1,702} & \multicolumn{2}{|r|}{1,313} & \multicolumn{2}{|r|}{905} & & \\
\hline & \multicolumn{2}{|c|}{ Netherlands } & \multicolumn{2}{|c|}{ Italy } & \multicolumn{2}{|c|}{ Spain } & \multicolumn{2}{|c|}{ Belgium } & \multicolumn{2}{|c|}{ Total } \\
\hline & $X$ & $R$ & $X$ & $R$ & $X$ & $R$ & $X$ & $R$ & $X$ & $R$ \\
\hline Median & 0.093 & 0.105 & 0.059 & 0.006 & 0.069 & 0.031 & 0.070 & 0.077 & 0.065 & 0.036 \\
\hline Mean & 0.087 & 0.158 & 0.037 & 0.054 & 0.022 & 0.144 & 0.066 & 0.141 & 0.046 & 0.094 \\
\hline Maximum & 0.611 & 1.471 & 0.536 & 2.023 & 1.344 & 3.437 & 0.831 & 1.882 & 1.344 & 4.672 \\
\hline Minimum & 0.377 & 0.601 & 0.732 & 0.619 & 2.928 & 0.825 & 0.536 & 0.534 & 2.928 & 0.825 \\
\hline Std dev. & 0.100 & 0.373 & 0.147 & 0.378 & 0.345 & 0.570 & 0.123 & 0.361 & 0.142 & 0.407 \\
\hline Observations & \multicolumn{2}{|c|}{680} & \multicolumn{2}{|r|}{624} & \multicolumn{2}{|r|}{419} & \multicolumn{2}{|r|}{378} & \multicolumn{2}{|c|}{12,306} \\
\hline
\end{tabular}

$X$ : Earnings after extraordinary items per share deflated by market share price at the beginning of the period; $R$ : Market returns $\left(P_{t}-P_{t}{ }_{1}\right) / P_{t}{ }_{1}$. 
the UK to 378 for Belgium. When we include all code-law-based countries as a group (in this case France, Germany, Italy, Spain, Belgium and Switzerland), we consider a sample of 5,341 firm-year observations.

\section{Research Design}

Balance sheet conservatism. As a first attempt to examine the existence of balance sheet conservatism, we use a similar approach to the one used by Givoly and Hayn (2000), where they analyse the evolution of the market-to-book ratio. They argue that the appropriate way to study the existence of this type of conservatism is aggregating the market value of all firms in the sample (per year, at the balance sheet date) and the book value of shareholders' equity at year end (per year), obtaining then the value of the market-to-book ratio of the country for each year.

However, prior literature has failed to establish a theoretical link between the market-to-book ratio and conservatism. The market-to-book ratio can be driven by many other factors (growth options, the possibility of monopoly rents and/or synergies, inflation, etc.). Consequently, we investigate (model) the effects of balance sheet conservatism using a valuation framework provided by Ohlson (1995), which expresses price as a function of both earnings and book value of equity:

$$
P_{t}=\alpha+\beta N I+\gamma B V+u
$$

where $P_{t}$ is share price at the balance sheet date, $N I$ is earnings after extraordinary items per share, ${ }^{15} \mathrm{BV}$ is period-end book value of shareholders' equity per share and $u$ is the disturbance term.

If balance sheet conservatism exists, and as Feltham and Ohlson (1995), Beaver and Ryan (2000) and Zhang (2000) point out, this would be reflected in the understatement of book value of equity. If this happens, we would be measuring one of the explanatory variables $(B V)$ with error.

The appropriate specification of the model would be: ${ }^{16}$

$$
P_{t}=\alpha+\beta N I+\gamma B V^{*}+u
$$

where $B V^{*}$ is the true value of shareholders' equity, that is, without the effect of conservatism. We define $B V^{*}$ (true book value of equity) as $B V$ (reported conservative book value of equity) plus $U R G W$ (unrecognized goodwill):

$$
B V^{*}=B V+U R G W
$$

At the same time, we split unrecognized goodwill, taking into account whether or 
not it is related to the actual book value of equity $(B V)$ :

$$
\begin{gathered}
U R G W=U R G W(A)+U R G W(B) \\
\operatorname{cov}[B V, U R G W(A)]>0 \\
\operatorname{cov}[B V, U R G W(B)]=0
\end{gathered}
$$

When we specify the model in terms of reported book value, and not in terms of true book value $\left(B V^{*}\right)$, we omit two variables in the model: $U R G W(A)$ and $U R G W(B)$. That is, the complete model should be:

$$
P_{t}=\alpha+\beta N I+\gamma B V+\phi U R G W(A)+\psi U R G W(B)+u
$$

We hypothesize that the existence of $U R G W(B)$ is mainly attributable to regulatory effects leading to the understatement of shareholders' equity, and that $U R G W(A)$ is mainly driven by accounting choice, and the result will also be the understatement of shareholders' equity.

On the one hand, the omission of $U R G W(A)$ will be affecting coefficient $\gamma$, which will be biased upwards. On the other hand, the omission of $U R G W(B)$ will be affecting the intercept, which, again, will be biased upwards. We should also consider that $\gamma$ can be biased downwards due to errors in variables problems.

To test the differential balance sheet conservatism in every country with respect to the UK, we use the following comparative model, where we include the differential effect of each country in each coefficient using dummy variables:

$$
P_{t}=\alpha+\sum_{j} \alpha_{j} C D_{j}+\beta N I+\sum_{j} \beta_{j} N I C D_{j}+\gamma B V+\sum_{j} \gamma_{j} B V C D j+u
$$

where $P_{t}, N I$ and $B V$ are defined as in the 'simple' model, and $C D_{j}$ is a dummy variable that takes value 1 if country $j$ and 0 otherwise. The reference country is the United Kingdom, which we choose as the reference country since it is a priori the most different country among those in our sample. If continental countries are more balance sheet conservative than the UK, we expect $\alpha_{j}$ and $\gamma_{j}$ to be significantly positive.

The inclusion of earnings in the model is not trivial. The book value multiple in the model will be affected by persistence of earnings. We expect $\beta_{j}$ to be capturing differences in earnings persistence between countries and we should interpret $\gamma_{j}$, bearing in mind that it is negatively related to the book value multiple. That is:

$$
\frac{\partial \gamma}{\partial \beta}<0
$$

Consequently, any claim regarding balance sheet conservatism focusing on the book value multiple $(\gamma)$ should be done analysing also the effect of the earnings multiple $(\beta)$. 
Seeking to avoid possible cross-sectional dependence problems, we run Fama and McBeth (1973) annual regressions. ${ }^{17} \mathrm{We}$ also test whether the models that we propose to analyse balance sheet conservatism can be affected by scale problems. By scale problems we refer to the fact that those companies with large market capitalization figures will probably have large values of accounting numbers like shareholders' equity or earnings. This leads to problems of heteroscedasticity and, what is even worse, the results could not be reflecting the economic relationships under study. This is a problem that cannot be completely solved using per share variables, since in this case the problem would be that those companies with a large share price will have large figures of shareholders' equity per share or earnings per share.

If we interpret, as Lo and Lys (2000) or Easton and Sommers (2003), that scale is the independent variable of the model, then the proposed solution to remove scale problems is deflating the model by share price at the beginning of the period. Lo and Lys (2000) deflate all variables, but not the intercept, which could be changing the nature of the economic relationship under study. This is why Easton and Sommers (2003) propose the deflation of the whole model, inclusive of the intercept. That is, they propose using a model without intercept and including the inverse of the scale proxy as an additional explanatory variable. We implement both specifications to control for scale. ${ }^{18}$

On the other hand, Barth and Kallapur (1996) and Barth and Clinch (2000) argue that scale is an omitted explanatory variable. They state that introducing a proxy for scale as an additional explanatory variable would reduce or eliminate scale problems. We also implement this correction to the models, including three different proxies for scale: market capitalization, number of shares and sales.

We expect that if the model is not affected by scale problems, then the coefficients of book value and earnings will not change with respect to those obtained with the initial model.

Earnings conservatism. To test our third hypothesis we use the 'simple' model proposed by Basu (1997), while to analyse our fourth hypothesis we will use the 'comparative' model proposed by Ball et al. (2000). Basu's 'simple' model is:

$$
X_{t}=\beta_{0}+\beta_{1} D+\beta_{2} R_{t}+\beta_{3} R_{t} D+u
$$

where $X_{t}$ is earnings after extraordinary items per share deflated by share price at the beginning of the period, $R_{t}$ is the rate of return of the firm, ${ }^{19}$ that is, $\left(\begin{array}{lll}P_{t} & P_{t} & 1\end{array}\right) /$ $P_{t}{ }_{1}$. Share prices have been adjusted for stock splits, new equity issues, etc.; $D$ is a dummy variable that takes value 1 in case of bad news (negative or zero rate of return) and 0 in case of good news (positive rate of return). We expect that $\beta_{3}$, which shows differential earnings sensitivity to bad news, will be significantly positive. 
Focusing on country differences, the model that Ball et al. (2000) use, which we refer to as the 'comparative' model, is the following:

$$
\begin{aligned}
X_{t}= & \beta_{0}+\sum_{j} \beta_{0 j} C D_{j}+\beta_{1} D+\sum_{j} \beta_{1 j} C D_{j} D+\beta_{2} R_{t}+\sum_{j} \beta_{2 j} C D_{j} R_{t} \\
& +\beta_{3} R_{t} D+\sum_{j} \beta_{3 j} R_{t} C D_{j} D+u
\end{aligned}
$$

where $X_{t}, R_{t}$ and $D$ are as defined in the 'simple model' and $C D_{j}$ is the dummy variable of country $j$. It takes value 0 if it is the case of the United Kingdom, and 1 if it is country $j$. We use the United Kingdom as reference country, given that it is a priori the most different of all countries under study.

This model is derived from the simple model of Basu (1997), incorporating the differences across countries through dummy variables. Contrarily to Ball et al. (2000), and following Pope and Walker (1999), we use earnings after extraordinary items per share, deflated by share price at the beginning of the period. We use this definition of earnings, and not earnings before extraordinary items, to try to avoid that our results could be seriously influenced by a different classification of good and bad news in financial statements across countries.

We expect that $\beta_{3 j}$, which shows the differential earnings response to bad news in continental countries with respect to the UK, will be significantly negative, showing the faster recognition of bad news in the UK.

Sensitivity analysis. In our study we assume, as for example in Joos and Lang (1994), that the underlying economies of European countries are fairly similar and, consequently, our results should not be influenced by, for example, macroeconomic factors. However, they could be seriously influenced by a different sample composition in each country, that is, by the so-called withincountry factors.

To test whether our results are influenced by within-country factors, we undertake a sensitivity analysis taking into account firm size and firm growth in the case of balance sheet conservatism, and firm size ${ }^{20}$ firm growth and balance sheet conservatism in the case of earnings conservatism. Analysing the sensitivity of our results regarding earnings conservatism to changes in the market-to-book ratio will also shed some light on whether higher balance sheet conservatism implies lower earnings conservatism. We split the sample into several subsamples according to the factors mentioned, and replicate all our analyses. If the results remain approximately the same, then we will be able to affirm that our results are not influenced by a different sample composition in each country. As proxies for size and growth we use market capitalization and percentage growth in assets. 
Table 3. Hypothesis 1: Evolution of the aggregate market to book ratio

\begin{tabular}{|c|c|c|c|c|c|c|c|c|}
\hline $\begin{array}{l}\text { Year } \\
\text { Switzerland }\end{array}$ & UK & Belgium & France & Germany & Italy & Netherlands & Spain & \\
\hline 1987 & 1.86 & 1.26 & 1.18 & 1.38 & 0.68 & 1.09 & 0.67 & 1.39 \\
\hline 1988 & 1.86 & 1.53 & 1.64 & 1.47 & 1.12 & 1.05 & 0.86 & 1.67 \\
\hline 1989 & 2.19 & 1.84 & 1.69 & 1.85 & 1.24 & 1.08 & 1.10 & 1.77 \\
\hline 1990 & 1.85 & 1.50 & 1.40 & 1.61 & 0.79 & 0.97 & 0.95 & 1.54 \\
\hline 1991 & 1.93 & 1.42 & 1.46 & 1.64 & 0.72 & 1.05 & 1.08 & 1.69 \\
\hline 1992 & 2.19 & 1.40 & 1.51 & 1.48 & 0.70 & 1.09 & 1.02 & 1.90 \\
\hline 1993 & 2.45 & 1.66 & 1.80 & 1.90 & 1.00 & 1.46 & 1.55 & 2.15 \\
\hline 1994 & 2.33 & 1.60 & 1.53 & 1.92 & 1.12 & 1.48 & 1.29 & 2.90 \\
\hline 1995 & 2.32 & 1.68 & 1.52 & 1.96 & 1.31 & 1.68 & 1.40 & 3.01 \\
\hline 1996 & 2.70 & 1.87 & 1.77 & 2.18 & 1.55 & 2.18 & 1.53 & 3.39 \\
\hline 1997 & 2.35 & 2.04 & 2.03 & 2.53 & 2.01 & 2.61 & 1.87 & 3.96 \\
\hline 1998 & 2.78 & 2.86 & 2.38 & 2.87 & 2.56 & 4.53 & 2.48 & 4.05 \\
\hline 1999 & 2.79 & 5.91 & 4.12 & 3.19 & 2.53 & 3.55 & 3.25 & 4.10 \\
\hline 2000 & 2.18 & n.a. & n.a. & n.a. & n.a. & 3.33 & n.a. & n.a. \\
\hline$t$ test & 26.68 & 10.70 & 26.04 & 3.42 & 1.55 & 9.82 & 1.52 & 1.79 \\
\hline$p$ value & 0.00 & 0.00 & 0.00 & 0.00 & 0.12 & 0.00 & 0.13 & 0.07 \\
\hline
\end{tabular}

Aggregate market to book ratio calculated as market capitalization of all firms in our sample divided by the total sum of shareholders' equity of all firms in our sample. The $t$ test and $p$ value refer to whether the aggregate market to book ratio is on average greater than one. The market to book ratio is significantly different (Mann Whitney test) in the UK than in the other countries in the sample. 


\section{Results}

\section{Hypothesis 1: Balance Sheet Conservatism}

As we can see in Table 3, except for one year in the Netherlands, three in Spain and four in Italy, in all the other countries/years (from a total of 106) the marketto-book ratio is greater than one. We can see that, much as expected, all countries show a market-to-book ratio greater than one. Besides, it is also interesting to point out that the eight unexpected values of the market-to-book ratio are all in the early years of our analysis, and that they are coincident in time with financial market drops and high inflation periods in countries like Spain or Italy. We also check whether the market-to-book ratio is on average significantly greater than

Table 4. Hypothesis 2: International comparison on balance sheet conservatism through the Feltham and Ohlson (1995) model

\begin{tabular}{lrr}
\hline Intercept & Pooled & Fama and McBeth \\
\hline UK $($ Ref. $)(\alpha)$ & 1.2988 & 1.2435 \\
& 42.1967 & 17.8362 \\
Belgium $\left(\alpha_{j}\right)$ & 58.2490 & 63.0365 \\
& 5.0130 & 4.6474 \\
France $\left(\alpha_{j}\right)$ & 24.5235 & 24.0272 \\
& 13.2637 & 9.8713 \\
Germany $\left(\alpha_{j}\right)$ & 82.2395 & 92.2037 \\
& 20.6850 & 8.1226 \\
Italy $\left(\alpha_{j}\right)$ & 0.3492 & 0.3342 \\
& 2.4399 & 2.3306 \\
Netherlands $\left(\alpha_{j}\right)$ & 5.5853 & 2.8522 \\
& 2.6170 & 0.8720 \\
Spain $\left(\alpha_{j}\right)$ & 4.5262 & 4.4324 \\
Switzerland $\left(\alpha_{j}\right)$ & 5.9929 & 5.9742 \\
& 226.3338 & 6.10 .6058 \\
All continental $\left(\alpha_{j}\right)$ & 6.9235 & 6.1595 \\
& 40.4179 & 40.5341 \\
& 11.0958 & 8.1348 \\
\hline
\end{tabular}

Normal model:

$$
P_{t}=\alpha+\sum_{j} \alpha_{j} C D_{j}+\beta N I+\sum_{j} \beta_{j} N I C D_{j}+\gamma B V+\sum_{j} \gamma_{j} B V C D_{j}+u
$$

$P$ : Share price; $N I$ : Earnings after extraordinary items per share; $B V$ : Shareholders' equity per share; $C D$ : Country dummy. Reference country: UK. All continental: Germany, France, Italy, Spain and Belgium. We use the Fama and McBeth (1973) methodology to cope with the possible cross sectional dependence problems. The coefficients of the parameters have been obtained as the simple average from annual cross section regressions. The $t$ statistics are the ratios of the mean estimated coefficients to the standard deviation of the distribution of the annual estimated slope coefficients, divided by the square root of the number of years. For the pooled regression, $t$ statistics are White (1980) heteroscedasticity consistent. 
one. Using a $t$-test (see also Table 3 ) we see that it is significantly greater than one in all countries at the $1 \%$ level ( $7 \%$ for Switzerland, $12 \%$ for Italy and $13 \%$ for Spain). The smaller $t$-statistics for Italy and Spain are also driven to some extent by high inflation rates in the early years of the analysis. We also find that the market-to-book ratio in the UK is significantly different from the market-to-book ratio of the other countries in the sample (using a Mann Whitney test).

\section{Hypothesis 2: Larger Balance Sheet Conservatism of Code-law-based Countries}

If we focus on the intercept of the undeflated regression of price on earnings and book value (see Table 4) we see that, consistent with our hypothesis, it is always significantly smaller in the UK (except in the case of Italy). That is, regulation leads directly to the understatement of assets.

In Table 5, we show the coefficients on earnings and book value. Analysing firstly the results for the normal undeflated model, we see that the differential book value coefficient of continental countries with respect to the UK is positive and statistically significant. It is also significantly positive in the individual cases of France, Germany and Belgium. In this case, management discretion, i.e. accounting choice, leads to an additional understatement of assets relative to market's valuation, and this additional understatement is greater in continental countries.

Nevertheless, we also see that the differential net income multiple in continental countries with respect to the UK is significantly negative. This could be attributable to differences in earnings persistence between countries, ${ }^{21}$ leading to investors giving more valuation weight to shareholders' equity when earnings are less persistent. We should consequently consider that our comparative results for balance sheet conservatism analysing the book value multiple, could be also affected (driven) by differences in persistence of earnings and in firm growth across countries. We explicitly undertake a sensitivity analysis to discard the possibility that differences in firm growth drive our results.

When we run Fama and McBeth (1973) mean annual regressions to remove any possible cross-sectional dependence problems, the results remain approximately the same. Focusing on deflated specifications, which we use to control for scale (columns 1 and 2 in Table 5), although the coefficients of book value and net income change (they become smaller), the differences between the UK and continental countries continue to hold. This reduction in the coefficients is especially significant in the specification where we do not deflate the intercept. However, not deflating the intercept is probably changing the economic nature of the problem under study, and we should be more confident on the specification where the intercept is also deflated. We should, however, point out again that this decrease in the coefficients is not affecting our conclusions regarding the differences between countries. Regarding the coefficient on earnings, we see when we deflate, the Netherlands, Spain and Switzerland, which showed a larger earnings multiple than the UK in the undeflated models, show now a smaller 
Table 5. Hypothesis 2: International comparison on balance sheet conservatism through the Feltham and Ohlson (1995) model

\begin{tabular}{|c|c|c|c|c|c|c|c|}
\hline$N I$ & Normal & $\begin{array}{l}\text { Fama and } \\
\text { McBeth }\end{array}$ & 1 & 2 & 3 & 4 & 5 \\
\hline \multirow[t]{2}{*}{ UK (Ref.) $(\beta)$} & 5.6651 & 5.6699 & 1.7083 & 3.0969 & 5.9289 & 6.1005 & 4.7270 \\
\hline & 31.7610 & 17.5285 & 15.4393 & 23.2634 & 24.7606 & 40.8299 & 10.2910 \\
\hline \multirow{2}{*}{ Belgium $\left(\beta_{j}\right)$} & 5.0685 & 2.1971 & 0.0784 & 1.2482 & 2.6812 & 2.8522 & 1.4840 \\
\hline & 6.2618 & 2.5447 & 0.1050 & 2.2706 & 3.4707 & 3.8038 & 1.7206 \\
\hline \multirow[t]{2}{*}{ France $\left(\beta_{j}\right)$} & 1.1260 & 1.5246 & 0.5353 & 1.7574 & 0.7998 & 0.9687 & 0.3736 \\
\hline & 2.5613 & 4.8245 & 1.9345 & 4.3059 & 2.0144 & 2.7560 & 0.6698 \\
\hline \multirow[t]{2}{*}{ Germany $\left(\beta_{j}\right)$} & 3.1358 & 2.7900 & 1.2958 & 2.8534 & 3.1334 & 3.3029 & 1.9462 \\
\hline & 9.2179 & 5.2354 & 7.7827 & 12.6052 & 8.6259 & 10.6368 & 3.6871 \\
\hline \multirow{2}{*}{ Italy $\left(\beta_{j}\right)$} & 1.4316 & 0.7671 & 0.4384 & 0.7982 & 1.4295 & 1.5006 & 0.3084 \\
\hline & 2.8174 & 0.9384 & 2.0889 & 2.5189 & 3.3143 & 3.5549 & 0.2933 \\
\hline \multirow[t]{2}{*}{ Netherlands $\left(\beta_{j}\right)$} & 0.5415 & 0.5252 & 0.9215 & 1.7693 & 2.2603 & 2.4143 & 1.3264 \\
\hline & 0.5404 & 0.4326 & 3.6928 & 3.3380 & 5.6606 & 6.6672 & 2.5717 \\
\hline \multirow{2}{*}{ Spain $\left(\beta_{j}\right)$} & 0.7898 & 1.4835 & 1.2973 & 2.2072 & 1.1193 & 0.9609 & 2.1989 \\
\hline & 1.1890 & 1.5737 & 7.4504 & 9.1513 & 1.7080 & 1.5218 & 2.9151 \\
\hline \multirow{2}{*}{ Switzerland $\left(\beta_{j}\right)$} & 1.9016 & 1.4440 & 1.4743 & 2.4520 & 0.9599 & 0.7892 & 2.1534 \\
\hline & 2.0332 & 2.2070 & 8.9482 & 9.1786 & 1.6337 & 1.4156 & 3.0262 \\
\hline \multirow[t]{2}{*}{ All continental $\left(\beta_{j}\right)$} & 4.1245 & 3.4533 & 0.8769 & 2.3228 & 2.6021 & 3.4087 & 1.2095 \\
\hline & 6.5272 & 8.9308 & 4.8101 & 11.1286 & 7.4235 & 10.8351 & 2.2932 \\
\hline \multicolumn{8}{|l|}{$B V$} \\
\hline \multirow[t]{2}{*}{ UK (Ref.) $(\gamma)$} & 0.5037 & 0.4995 & 0.0701 & 0.3381 & 0.4907 & 0.4979 & 0.3870 \\
\hline & 19.3882 & 28.6944 & 5.3277 & 17.9090 & 23.1269 & 24.4019 & 8.5821 \\
\hline \multirow{2}{*}{ Belgium $\left(\gamma_{j}\right)$} & 0.3844 & 0.1608 & 0.1300 & 0.4255 & 0.3720 & 0.3648 & 0.4762 \\
\hline & 4.2715 & 2.5956 & 1.7620 & 8.9192 & 4.1013 & 4.0297 & 4.8133 \\
\hline
\end{tabular}




\begin{tabular}{|c|c|c|c|c|c|c|c|}
\hline \multirow[t]{2}{*}{ France $\left(\gamma_{j}\right)$} & 0.2065 & 0.3017 & 0.1149 & 0.2491 & 0.2412 & 0.2339 & 0.3413 \\
\hline & 3.5505 & 3.5963 & 1.7976 & 3.4558 & 5.4771 & 5.3609 & 5.8152 \\
\hline \multirow[t]{2}{*}{ Germany $\left(\gamma_{j}\right)$} & 0.3892 & 0.2902 & 0.2121 & 0.6960 & 0.5546 & 0.5463 & 0.6505 \\
\hline & 6.4736 & 2.7279 & 6.4757 & 16.1518 & 10.0154 & 9.9009 & 9.6837 \\
\hline \multirow[t]{2}{*}{ Italy $\left(\gamma_{j}\right)$} & 0.0625 & 0.0323 & 0.0169 & 0.1092 & 0.0570 & 0.0446 & 0.1016 \\
\hline & 0.7655 & 0.3484 & 0.6389 & 0.8166 & 1.0093 & 0.8107 & 1.0409 \\
\hline \multirow[t]{2}{*}{ Netherlands $\left(\gamma_{j}\right)$} & 0.0244 & 0.0202 & 0.0472 & 0.2114 & 0.1117 & 0.1041 & 0.1947 \\
\hline & 0.2358 & 0.2236 & 1.1921 & 2.8902 & 1.8173 & 1.7030 & 2.5912 \\
\hline \multirow[t]{2}{*}{ Spain $\left(\gamma_{j}\right)$} & 0.0298 & 0.0930 & 0.2086 & 0.3958 & 0.0554 & 0.0455 & 0.1778 \\
\hline & 0.3218 & 0.9787 & 2.9174 & 6.9604 & 0.6716 & 0.5556 & 1.8801 \\
\hline \multirow[t]{2}{*}{ Switzerland $\left(\gamma_{j}\right)$} & 0.1089 & 0.0406 & 0.0390 & 0.1138 & 0.0704 & 0.0776 & 0.0338 \\
\hline & 1.3937 & 0.4301 & 0.6411 & 1.2735 & 1.3323 & 1.4797 & 0.5114 \\
\hline \multirow{2}{*}{ All continental $\left(\gamma_{j}\right)$} & 0.4638 & 0.4475 & 0.1381 & 0.5385 & 0.5222 & 0.5054 & 0.6418 \\
\hline & 8.9874 & 14.4025 & 3.5190 & 12.5102 & 13.3762 & 12.2103 & 11.2105 \\
\hline
\end{tabular}

Normal model:

$$
P_{t}=\alpha+\sum_{j} \alpha_{j} C D_{j}+\beta N I+\sum_{j} \beta_{j} N I C D_{j}+\gamma B V+\sum_{j} \gamma_{j} B V C D_{j}+u
$$

$P$ : Share price; $N I$ : Earnings after extraordinary items per share; $B V$ : Shareholders' equity per share; $C D$ : Country dummy. Reference country: UK. All continental: Germany, France, Italy, Spain and Belgium. We use the Fama and McBeth (1973) methodology to cope with the possible cross sectional dependence problems. The coefficients of the parameters have been obtained as the simple average from annual cross section regressions. The $t$ statistics are the ratios of the mean estimated coefficients to the standard deviation of the distribution of the annual estimated slope coefficients, divided by the square root of the number of years. (1) Following Lo and Lys (2000), to cope with the possible scale problems, we deflate the model (except the intercept) by market share price at the beginning of the period. (2) Following Easton and Sommers (2003), also focusing on solving scale problems, we deflate again the model (including the intercept) by market share price at the beginning of the period. (3), (4) and (5) Barth and Kallapur (1996) and Barth and Clinch (2000) argue that scale could be an omitted explanatory variable in the normal model. To control for that we include as additional explanatory variables: in specification (3) market capitalization at balance sheet date, in specification (4) number of shares at balance sheet date, and in specification (5) sales. In all cases (except Fama and McBeth), $t$ statistics are White (1980) heteroscedasticity consistent. 
earnings multiple, consistent with earnings being more persistent in the UK. The only changes in signs for the book value coefficient are in cases where the coefficient is not, in any case, statistically significant.

When we incorporate additional explanatory variables in the model (see Table 5, columns 3, 4 and 5), as proxies for scale, the coefficients remain very close to the ones that we obtain with the normal model; the differences between countries are also similar. The only country that suffers a consistent change in sign is the Netherlands, which after the scale correction behaves like continental countries.

Taking into account our results for the five specifications that we use to control for scale, we think that, although the coefficients change in the deflated specifications, our comparative results are not driven by scale problems since the differences between countries are always present, and they are always statistically significant.

\section{Hypothesis 3: Earnings Conservatism}

As we pointed out before, to test this third hypothesis we use Basu's 'simple' model. We expect all countries under study to show earnings conservatism, namely, an asymmetric recognition of good and bad news in earnings, recognizing bad news on a timelier basis than good news. We can see these results (using both pooled and Fama and McBeth annual regressions) in Table 6 .

If we focus on continental countries on an individual basis, we see that in all countries there is a significant faster recognition of bad news in earnings with respect to good news, that is, coefficient $\beta_{3}$ is in all cases statistically significant (except in the case of Italy). When we run a pooled regression with continental countries (Germany, France, Switzerland, Italy, Spain and Belgium), the asymmetry is also statistically significant. ${ }^{22}$

If we focus on the intercept of the model $\left(\beta_{0}+\beta_{1}\right)$, we can see that it is in all cases positive and statistically significant. As Basu (1997) points out, the intercept will be reflecting the incorporation in this year's earnings of priorperiod good news that was not captured in earnings in the period when they initially appeared. Although the intercept of these models could be affected by many other omitted variables, for example the cost of capital, we must take into account that it is very likely that the main factor affecting it will be prior-period news. In several studies like Easton et al. (1992) or Warfield and Wild (1992), where they analyse the association between earnings and returns, they obtain $R^{2}$, s of around $10 \%$ using a measurement window of one year, and of around $70 \%$ when they use a measurement window of ten years. It is logical, then, thinking that this factor that makes the coefficient of determination grow from $10 \%$ to $70 \%$ will be the main factor affecting the intercept.

Some authors, like Ball et al. (2003) or Basu (2001), also argue that the intercept of the Basu (1997) type reverse regression would also be reflecting the relationship between balance sheet and earnings conservatism. They argue that if 
Table 6. Hypothesis 3: Earnings conservatism

\begin{tabular}{|c|c|c|c|c|c|c|c|c|c|c|c|}
\hline \multirow[b]{2}{*}{ Country } & \multicolumn{5}{|c|}{ Pooled regressions } & \multicolumn{5}{|c|}{ Fama and MacBeth (1973) annual regressions } & \multirow[b]{2}{*}{ No. obs. } \\
\hline & $\beta_{0}(t)$ & $\beta_{1}(t)$ & $\beta_{2}(t)$ & $\beta_{3}(t)$ & Adj. $R^{2}$ & $\beta_{0}(t)$ & $\beta_{1}(t)$ & $\beta_{2}(t)$ & $\beta_{3}(t)$ & Adj. $R^{2}$ & \\
\hline \multirow[t]{2}{*}{ United Kingdom } & 0.0735 & 0.0032 & 0.0140 & 0.2431 & 0.1351 & 0.0711 & 0.0016 & 0.0210 & 0.2560 & 0.1436 & 6,285 \\
\hline & 29.2419 & 0.6824 & 1.9536 & 12.7853 & & 8.9760 & 0.4606 & 2.3449 & 8.1563 & & \\
\hline \multirow[t]{2}{*}{ Belgium } & 0.0567 & 0.0182 & 0.0805 & 0.1437 & 0.0775 & 0.0862 & 0.0110 & 0.0150 & 0.4107 & 0.1203 & 378 \\
\hline & 4.9310 & 0.8543 & 3.4033 & 1.7457 & & 3.0691 & 0.2193 & 0.3813 & 2.5642 & & \\
\hline \multirow[t]{2}{*}{ France } & 0.0605 & 0.0025 & 0.0520 & 0.1903 & 0.1315 & 0.0611 & 0.0045 & 0.0467 & 0.2892 & 0.1894 & 1,313 \\
\hline & 10.1469 & 0.2303 & 3.7740 & 4.2917 & & 7.5114 & 0.3304 & 2.6834 & 4.2594 & & \\
\hline \multirow[t]{2}{*}{ Germany } & 0.0409 & 0.0062 & 0.0315 & 0.1343 & 0.0787 & 0.0497 & 0.0150 & 0.0340 & 0.1186 & 0.0811 & 1,702 \\
\hline & 11.2126 & 0.9513 & 3.0484 & 4.0879 & & 6.0071 & 2.3561 & 1.9201 & 2.6305 & & \\
\hline \multirow[t]{2}{*}{ Italy } & 0.0435 & 0.0030 & 0.0737 & 0.0808 & 0.0670 & 0.0485 & 0.0092 & 0.0830 & 0.0620 & 0.0588 & 624 \\
\hline & 3.8400 & 0.1575 & 2.6791 & 1.2918 & & 2.4720 & 0.8987 & 2.7396 & 0.6846 & & \\
\hline \multirow[t]{2}{*}{ Netherlands } & 0.0933 & 0.0122 & 0.0543 & 0.1462 & 0.1569 & 0.0958 & 0.0359 & 0.0558 & 0.1222 & 0.2428 & 680 \\
\hline & 14.1364 & 1.0580 & 2.7837 & 3.0583 & & 10.5989 & 2.5837 & 2.3102 & 2.2997 & & \\
\hline \multirow[t]{2}{*}{ Spain } & 0.0618 & 0.0359 & 0.0375 & 0.5184 & 0.0770 & 0.0943 & 0.0094 & 0.2366 & 0.7631 & 0.1622 & 419 \\
\hline & 2.1761 & 0.7582 & 0.8863 & 2.9877 & & 2.1459 & 0.3659 & 0.8060 & 2.0404 & & \\
\hline \multirow[t]{2}{*}{ Switzerland } & 0.0599 & 0.0025 & 0.0485 & 0.2666 & 0.0929 & 0.0633 & 0.0059 & 0.0403 & 0.3340 & 0.1271 & 905 \\
\hline & 8.0326 & 0.1456 & 3.4625 & 3.0073 & & 7.2895 & 0.5343 & 2.6821 & 3.3942 & & \\
\hline \multirow[t]{2}{*}{ All continental } & 0.0512 & 0.0071 & 0.0509 & 0.2213 & 0.0832 & 0.0549 & 0.0032 & 0.0449 & 0.2595 & 0.1076 & 5,341 \\
\hline & 14.1176 & 0.9938 & 5.7580 & 6.1872 & & 6.8653 & 0.5823 & 3.2071 & 5.7468 & & \\
\hline
\end{tabular}

Model:

$$
X_{t}=\beta_{0}+\beta_{1} D+\beta_{2} R_{t}+\beta_{3} R_{t} D+u
$$



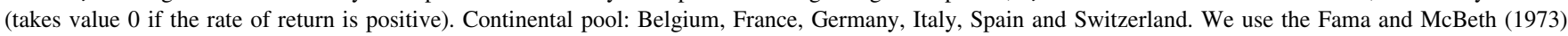

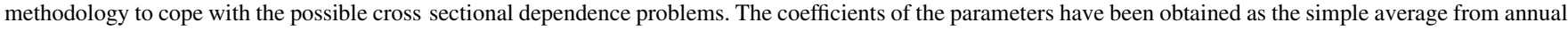

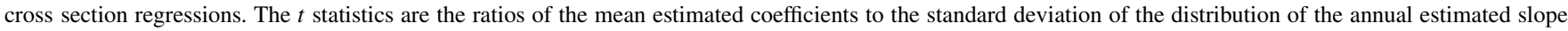
coefficients, divided by the square root of the number of years. Pooled regression $t$ statistics are White (1980) heteroscedasticity consistent. 
balance sheet conservatism is more pronounced, then the intercept should be capturing this, and it would be smaller. Using the comparative model proposed for Hypothesis 4, we find that the intercept is significantly smaller in Germany, France and Italy than in the UK. However, this result, consistent with larger balance sheet conservatism in continental countries, is difficult to interpret due to the asynchrony between the variables, which is also captured by the intercept.

\section{Hypothesis 4: Larger Earnings Conservatism in Common-law-based Countries}

To test this hypothesis we use the 'comparative model', which includes the differential effect of each country using dummy variables. This way of measuring the differences among countries allows us to check their statistical significance. As the reference country is the United Kingdom, which can be considered as the most extreme example in Europe of common-law-based countries, we expect that $\beta_{3 j}$ will be significantly negative for all continental countries, for the reasons already explained.

As we can see in Table 7, there is not a statistically significant difference in the level of earnings conservatism between the UK and the group of continental countries. $^{23}$ The only country that shows significantly smaller earnings conservatism than the UK is Germany.

Sensitivity analysis. Balance sheet conservatism: With respect to size, we split the sample into three sub-samples, and results for large and medium firms are similar to those obtained for the whole sample. However, in the case of small firms, the only country that shows larger balance sheet conservatism than the UK is Germany. When we focus on continental countries as a group, in all subsamples continental countries are significantly more balance sheet conservative than the UK. It is also interesting to point out the different behaviour of the UK and continental countries. In the UK, balance sheet conservatism tends to be less pronounced as firm size increases, while in continental countries exactly the opposite occurs (see Table 8).

Regarding growth, results are, in general, consistent with those obtained for the whole sample. We split the sample into four groups attending to growth in assets, and in the four sub-samples continental countries show larger balance sheet conservatism than the UK.

Earnings conservatism: With respect to size, we split the sample into three subsamples, using market capitalization as a proxy for size. We find that earnings conservatism is more pronounced in small firms. The comparative results are similar in the three sub-samples when we compare the UK with a pool of continental countries. The UK shows larger earnings conservatism than continental countries as a whole, but the difference is not statistically significant.

Regarding growth, we split the sample into four sub-samples using percentage growth in assets as a proxy for the growth of the firm. The comparative results of the UK with respect to the continental pooled in all the sub-samples are similar to 
Table 7. Hypothesis 4: International comparative analysis on earnings conservatism

\begin{tabular}{|c|c|c|c|c|}
\hline & \multicolumn{2}{|c|}{ Pooled } & \multicolumn{2}{|c|}{ Fama and MacBeth } \\
\hline & Coefficient & $t$ statistic & Coefficient & $t$ statistic \\
\hline \multicolumn{5}{|l|}{ Reference } \\
\hline$G N(\mathrm{UK})\left(\beta_{2}\right)$ & 0.0140 & 1.9517 & 0.0319 & 4.9557 \\
\hline$B N(\mathrm{UK})\left(\beta_{3}\right)$ & 0.2431 & 12.7728 & 0.2456 & 6.9400 \\
\hline \multicolumn{5}{|l|}{ Good news $\left(\beta_{2 j}\right)$} \\
\hline Belgium & 0.0665 & 2.6992 & 0.0169 & 0.3854 \\
\hline France & 0.0380 & 2.4459 & 0.0149 & 0.8267 \\
\hline Germany & 0.0175 & 1.3915 & 0.0140 & 0.6779 \\
\hline Italy & 0.0597 & 2.1032 & 0.0504 & 1.6173 \\
\hline Netherlands & 0.0403 & 1.9415 & 0.0187 & 0.6615 \\
\hline Spain & 0.0235 & 0.5496 & 0.2922 & 0.8491 \\
\hline Switzerland & 0.0345 & 2.1930 & 0.0053 & 0.3054 \\
\hline All continental & 0.0368 & 3.2372 & 0.0240 & 1.5391 \\
\hline \multicolumn{5}{|l|}{ Bad news $\left(\beta_{3 j}\right)$} \\
\hline Belgium & 0.0994 & 1.1815 & 0.1651 & 1.0534 \\
\hline France & 0.0528 & 1.0941 & 0.1113 & 2.7162 \\
\hline Germany & 0.1087 & 2.8637 & 0.1350 & 2.6591 \\
\hline Italy & 0.1623 & 2.4861 & 0.1645 & 1.2547 \\
\hline Netherlands & 0.0969 & 1.8859 & 0.1021 & 1.6889 \\
\hline Spain & 0.2753 & 1.5825 & 0.5653 & 1.3214 \\
\hline Switzerland & 0.0235 & 0.2594 & 0.1271 & 1.3212 \\
\hline All continental & 0.0218 & 0.5376 & 0.0034 & 0.0650 \\
\hline Adjusted $R^{2}$ & 0.1171 & & 0.1689 & \\
\hline
\end{tabular}

Model:

$$
\begin{aligned}
X_{t}= & \beta_{0}+\sum_{j} \beta_{0 j} C D_{j}+\beta_{1} R D+\sum_{j} \beta_{1 j} C D_{j} R D+\beta_{2} R_{t}+\sum_{j} \beta_{2 j} C D_{j} R_{t} \\
& +\beta_{3} R_{t} R D+\sum_{j} \beta_{3 j} R_{t} C D_{j} R D+u
\end{aligned}
$$

where $X_{t}$ : Earnings after extraordinary items per share deflated by share price at the beginning of the period; $C D_{j}$ : Dummy variable (takes value 1 if it is country $j$ ). Value reference country UK. $R_{t}$ : Observed rate of return of firm $i$; $R D$ : Dummy variable (takes value 0 if the rate of return is positive). Pooled: Germany, France, Italy, Spain, Belgium and Switzerland. $t$ statistics are White (1980) heteroscedasticity consistent.

those obtained for the whole sample, that is, earnings conservatism in the UK is not significantly more pronounced than in continental countries. Through this sensitivity test we also find the explanation for the extremely large earnings response to bad news in Spain (twice the one in the UK, and three times larger than in the UK when using Fama and McBeth regressions). This result is driven by the existence of a large number of Spanish firms with a very pronounced decrease in assets. If we exclude these firms from the sample, then Spain behaves similarly to the other continental countries. This result for Spain is consistent with other studies, like Giner and Grambovas (2001) who argue that the result is 
Table 8. Sensitivity analysis: Balance sheet conservatism; firm size

\begin{tabular}{|c|c|c|c|c|}
\hline & \multicolumn{2}{|c|}{ UK (Ref.) } & \multicolumn{2}{|c|}{ All continental } \\
\hline & $\begin{array}{l}N I(\beta) \\
t \text { statistic }\end{array}$ & $\begin{array}{c}B V(\gamma) \\
t \text { statistic }\end{array}$ & $\begin{array}{c}N I\left(\beta_{j}\right) \\
t \text { statistic }\end{array}$ & $\begin{array}{c}B V\left(\gamma_{j}\right) \\
t \text { statistic }\end{array}$ \\
\hline \multirow[t]{2}{*}{ Small } & 2.6258 & 0.6053 & 0.5433 & 0.2464 \\
\hline & 12.9566 & 21.5129 & 1.3587 & 4.0239 \\
\hline \multirow[t]{2}{*}{ Medium } & 4.5842 & 0.4719 & 2.0381 & 0.5263 \\
\hline & 19.9809 & 14.7103 & 4.8608 & 9.7824 \\
\hline \multirow[t]{2}{*}{ Large } & 6.1666 & 0.3807 & 2.2266 & 0.8956 \\
\hline & 24.5261 & 10.9584 & 3.9450 & 12.6218 \\
\hline
\end{tabular}

Model:

$$
P_{t}=\alpha+\sum_{j} \alpha_{j} C D_{j}+\beta N I+\sum_{j} \beta_{j} N I C D_{j}+\gamma B V+\sum_{j} \gamma_{j} B V C D_{j}+u
$$

where $P_{t}$ : Share price; $C D_{j}$ : Country dummy variable (ref. UK); NI: Net income per share; $B V$ : Shareholders' equity per share. All continental: Germany, France, Italy, Spain and Belgium. Small: Less than $€ 27$ million of market capitalization. Medium: Between $€ 27$ and 156 million of market capitalization. Large: More than $€ 156$ million of market capitalization. The $N I$ and $B V$ coefficients for the UK (reference country) are respectively $\beta$ and $\gamma$, while for the other countries they are $\beta_{j}$ and $\gamma_{j}$, that is, the incremental coefficient with respect to the UK. $t$ statistics are White (1980) heteroscedasticity consistent.

attributable to firms with financial problems derived from the financial and monetary crisis at the beginning of the 1990s.

Finally, when we analyse the interaction between balance sheet conservatism and earnings conservatism, using the market-to-book ratio as a proxy for balance sheet conservatism, our results for the UK are not consistent with the asymmetry being less pronounced as the market-to-book ratio grows, but they are in the case of continental countries, where a priori it is more likely the existence of balance sheet conservative practices. ${ }^{24}$ In the comparative analysis (see Table 9), the larger earnings conservatism of the UK, although never statistically significant, is smaller when the market-to-book ratio is small. The larger earnings conservatism of the UK even disappears in the sub-sample with the smallest market-to-book ratio.

Our results are thus consistent with those in Pope and Walker (2003), that is, there exists a decrease in the level of asymmetry and earnings conservatism with the existence of balance sheet conservative practices.

\section{Conclusions and Implications}

The paper provides evidence on the existence of both balance sheet and earnings conservatism in Europe. We find that code-law-based countries are more balance sheet conservative. We check also the extent to which the UK shows larger 
Table 9. Sensitivity analysis: Effect of balance sheet conservatism (market to book ratio) on earnings conservatism (international comparative analysis)

\begin{tabular}{lccccr}
\hline \multicolumn{6}{c}{ Market to book ratio: UK vs continental pool } \\
\hline$\beta_{3 j}$ & $\begin{array}{c}t \text { statistic } \\
\text { Large }\end{array}$ & $B N$ coefficient $t$ statistic & $B N$ coefficient & $t$ statistic \\
& \multicolumn{2}{c}{ Medium } & Small & \\
\hline 0.0818 & 1.4686 & 0.0475 & 0.7107 & 0.0752 & 1.4650 \\
\hline
\end{tabular}

Model:

$$
\begin{aligned}
X_{t}= & \beta_{0}+\sum_{j} \beta_{0 j} C D_{j}+\beta_{1} R D+\sum_{j} \beta_{1 j} C D_{j} R D+\beta_{2} R_{t}+\sum_{j} \beta_{2 j} C D_{j} R_{t} \\
& +\beta_{3} R_{t} R D+\sum_{j} \beta_{3 j} R_{t} C D_{j} R D+u
\end{aligned}
$$

where $X_{t}$ : Earnings after extraordinary items per share deflated by share price at the beginning of the period; $C D_{j}$ : Dummy variable (takes value 1 if it is country $j$ ). Value reference country UK. $R_{t}$ : Observed rate of return of firm $i$; $R D$ : Dummy variable (takes value 0 if the rate of return is positive). Pooled: Germany, France, Italy, Spain, Belgium and Switzerland. We do not include the Netherlands, since it has been traditionally considered as a common law based oriented country. $t$ statistics are White (1980) heteroscedasticity consistent.

earnings conservatism than continental countries. Our results only indicate that the more pronounced earnings conservatism of the UK is statistically significant with respect to Germany, but not with respect to the other countries in the sample. This result, ${ }^{25}$ although not consistent with our hypothesis, is similar to the results in Giner and Rees (2001). One plausible explanation could be, as LaPorta et al. (1999) point out, that the differences between countries in the corporate ownership structure are not as pronounced as it has been typically assumed in the literature.

We also check that our results are not attributable to a different sample composition in each country, and also that they are not seriously influenced by scale problems. Regarding the interaction between balance sheet and earnings conservatism, our results suggests that balance sheet conservatism reduces earnings conservatism.

However, our results must be cautiously interpreted since several authors point out that 'the issue of conservatism is tied to the debate about whether the current level of stock prices represents a bubble' (Givoly and Hayn, 2000). This would affect mainly balance sheet conservatism. Other authors (Beaver et al., 1997; Francis and Schipper, 1999) argue that there could be a measurement error in returns, which would be biasing the slope of the reverse regression used to measure earnings conservatism. This last fact could be the explanation to why the smaller earnings conservatism of continental countries with respect to the UK is not statistically significant (another explanation could be that differences regarding the sources of finance are disappearing between common-law- and 
code-law-based countries, as LaPorta et al., 1999, point out). The results when we measure earnings conservatism could be also biased due to the fact that, as Hayn (1995) points out, losses are likely to be temporary since shareholders can always liquidate the firm rather than suffer from indefinite losses. Thus, when measuring earnings conservatism, we are probably facing important problems of survivor bias.

Finally, we should reflect on whether the usage of a common set of standards in Europe (IASB standards) will make the differences that we find disappear or if they will not. Although arguable and open to debate, our opinion is that with respect to the differences in balance sheet conservatism attributable to regulatory factors (the ones reflected in the intercept of a regression of price on book value and earnings), the usage of a common set of standards will help to reduce the differences that we find in balance sheet conservatism across countries. At least as long as the new set of standards do not provide managers with the possibility of choosing between a wide number of alternatives. Regarding balance sheet conservatism driven by management discretionary decisions (affecting the bookvalue multiple) we do not think that the differences between countries will disappear if the differences in development of financial markets and providers of finance remain across countries. Also, and as Ball et al. (2000) point out, the differences that we find in earnings conservatism are probably attributable, at least in part, to different behavioural patterns in every country that affect differently the accounting system, but that are not reflected in a set of standards. Thus, we think that the differences in earnings conservatism across countries will continue to hold even after implementing a common set of standards as long as the differences in institutional factors remain.

\section{Acknowledgements}

This paper is part of the Harmonia programme of research into accounting harmonization and standardization in Europe, and we acknowledge the financial contribution of the European Commission through the Human Potential Programme, contract HPRN-CT-2000-00062. It is also a result of the Marie Curie programme (University of Manchester), funded by the European Commission, contract HPMT-CT-2000-00067, as well as of the research project 'La convergencia contable como factor de competitividad empresarial en el mercado bursátil globalizado: el papel de los aspectos institucionales y empresariales en los países de la Unión Europea' funded by Ministerio de Ciencia y Tecnología (Spanish Ministry of Science and Technology), SEC2002-04608C02-02. The paper has benefited from presentations at the first Harmonia conference, held in Madrid in June 2001, at the 25th European Accounting Association annual congress, held in Copenhagen, in April 2002, at the Harmonia workshop held in Lancaster, in September 2002, at a CentER seminar at Tilburg University, in January 2003, and at the 5th Aidea Giovani conference, held in Milan in July 2003. We acknowledge the comments and suggestions by Philip Brown, 
Willem Buijink, Begoña Giner, Stuart McLeay, Ken Peasnell, Peter Pope, Maarten

Pronk, Bill Rees and two anonymous referees, as well as those by all the members of the Harmonia programme.

\section{Notes}

1. As Basu (1997) points out, Interpretation 14 (FASB, 1976) seems to be an exception to this rule.

2. It would be possible to understate earnings consistently if the firm is growing. See Zhang (2000, p. 133).

3. Basu (2001) identifies two types of earnings conservatism. The first type responds to the firm's commitment to allocate the original acquisition cost over the life of an asset in a certain pattern, without regard to concurrent information about changes in asset value (very similar to the Feltham and Ohlson, 1996, definition of conservatism). The second one focuses on the asymmetric recognition of news in earnings, which is the definition used by Basu (1997), Ball et al. (2000) or Giner and Rees (2001). When we talk in the paper about earnings conservatism we focus also on the asymmetry in news recognition in earnings.

4. Note that in the literature we find also a third type of conservatism, the Feltham and Ohlson (1996) conservatism type, resulting from the rapid expensing of operating assets. However, since the differences between market and accounting numbers driven by this type of conservatism are merely temporary, we would include it just as a type of earnings conservatism. For empirical evidence on this type of conservatism see Ahmed et al. (2000).

5. We use 'code law based' or 'continental' interchangeably throughout the paper. We refer to an accounting regime where financial institutions are the main providers of capital funds. In our sample, we include Germany, France, Italy, Belgium, Spain and Switzerland as code law or continental countries.

6. See also Zhang (2000) for an analytical development of the relationship between balance sheet and earnings conservatism.

7. Basu (1997) also argues that the increase in the timeliness of earnings over cash flows is greater for bad than for good news, that negative earnings changes have greater tendency to revert in the following period than positive earnings changes, and that 'good earnings news' (positive earnings changes) leads to larger announcement period abnormal returns than negative earnings changes.

8. Gigler and Hemmer (2001) argue that this asymmetry can also be driven by voluntary information provided by the firm.

9. See Kothari et al. (1988) and Skinner (1994).

10. Results of comparative studies on earnings conservatism can be affected by differences in income smoothing (see Leuz et al., 2003).

11. Basu et al. (2001) show that those firms audited by the Big Five (Six, Eight) auditing firms are more earnings conservative. Pope and Walker (2003) analyse how the understatement of shareholders' equity, as reflected in the market to book ratio, is affecting the measures of earnings conservatism. They find, for the US, that when the market to book ratio is small, earnings conservatism is more pronounced. Ryan and Zarowin (2003) analyse the relationship between earnings and returns, studying both the existence of earnings conservatism and of the prices leading earnings phenomenon. Helbok and Walker (2001) analyse the implication of earnings conservatism on analysts' earnings forecasts. Beekes et al. (2003) analyse whether earnings conservatism measures vary with the composition of the board of directors, and similarly, Huijgen and Lubberink (2001a) link earnings conservatism with 
managerial incentives. Garrod and Valentincic (2001) argue that the asymmetry can be explained by shareholders' liquidation option. Giner and Grambovas (2001) analyse the existence of earnings conservatism in ten European countries showing that the degree of earnings conservatism is larger in case of monetary crisis. Raonic et al. (2003), focusing on European interlisted firms, argue that differences between European countries can be explained by several institutional factors. Chandra et al. (2001) examine conservatism in US high tech firms. Finally, Huijgen and Lubberink (2001b) compare Dutch firms cross listing in the US with those that do not, finding the former more conservative.

12. Although in a completely different setting (the United States, early twentieth century and the railroads industry), Sivakumar and Waymire (2003) find evidence inconsistent with this hypothesis.

13. We also replicate all our analyses eliminating outliers (first and last percentile, on a country basis) from the residuals of the regressions we undertake. It is likely that through this robustness test we obtain coefficients of the parameters closer to their real values. However, our results are not sensitive to the exclusion of these observations.

14. We include in the continental group Germany, France, Italy, Spain and Belgium. We do not include the UK and the Netherlands, typically classified as common law based countries (see Nobes, 1983). For balance sheet conservatism we also exclude Switzerland from the continental group. If we focus on the descriptive statistics in Table 1, we can see that there is a larger variability of all variables in Switzerland, to the extent that if we include Switzerland in the continental group, Swiss observations would behave as outliers, and drive the results for the whole group.

15. Using bottom line earnings we are closer to maintaining the clean surplus relation, which Feltham and Ohlson (1995) models assume. Additionally, we are also consistent with the definition of earnings that we find more appropriate to measure earnings conservatism.

16. As in Feltham and Ohlson (1995), we assume a linear relationship between price and book value and earnings. Although empirical analysis of US data, i.e. Burgstahler and Dichev (1997), suggests that this relation is non linear, this is beyond the scope of our study. Nevertheless, we believe that further research targeting this particular misspecification of the model should be encouraged.

17. Our results obtained from applying the Fama and McBeth (1973) analysis should be interpreted with caution. The analysis by Fama and McBeth (1973) assumes that the relations between variables are stationary over time. However, in our theoretical analysis we assume that Western European countries are converging under the EU directives. Also, the aggregate market to book ratio increases systematically over time in most countries. Basu (2001) shows as well serious concerns about the results of the annual regressions of Fama and McBeth, when used in capital markets based accounting research.

18. To avoid the creation of artificial scale problems that could even lead to the non linearity of the model, we do not include, following Kothari and Zimmerman (1995), those observations where the deflator (price at the beginning of the period) is smaller than one euro. In Kothari and Zimmerman (1995) they exclude all observations where the deflator is smaller than three dollars.

19. We use, as Pope and Walker (1999) or Giner and Rees (2001), the rate of return exclusive of dividends. However, we replicate all our analyses including dividends, obtaining fairly similar results.

20. Giner and Rees (2001) find that earnings conservatism decreases as firm size increases. This is consistent with the results in Basu et al. (2001). See Basu (2001) for several explanations for this result. 
21. Greater persistence of earnings is one of the possible explanations as to why the earnings multiple is smaller in continental countries compared to the UK. Other explanations include, for instance, differences in growth (although this is not supported by our empirical evidence) and risk. Results in other papers, like Ball et al. (2000) or Leuz et al. (2003), suggesting greater income smoothing in code law based countries are not necessarily contrary to our results. Income smoothing leads to greater earnings persistence, but this does not necessarily imply that earnings persistence in continental countries will be greater than in the UK.

22. We also check whether the total bad news effect $\left(\beta_{2}+\beta_{3}\right)$ is statistically significant. For earnings conservatism to exist, it is not only necessarily a significant incremental sensitivity of bad news with respect to good news, but also that the total effect of bad news is statistically significant. We analyse this extent through a Wald test, finding that the total bad news response coefficient is significantly positive in all countries.

23. In the case of the pooled regression, if we compare the UK with the group of continental countries and exclude Spain and Switzerland from the analysis, the significance of the difference between the UK and the continental group would increase. But still, we could not strongly argue that there are significant differences, particularly taking into account that when we use Fama and McBeth regressions the differential coefficient of bad news in continental countries with respect to the UK is close to zero.

24. This result is not reported, but is available from the authors upon request.

25. This is contrary to our hypothesis (and also to what is hypothesized in previous studies), but not exactly contrary to the results in previous literature. Ball et al. (2000) choose the US as reference country, and find the US significantly more conservative than France and Germany (and also more conservative than the UK), but they do not test the significance of the differences between the UK, France and Germany. Also, Giner and Rees (2001) do not find significant differences among the countries in their sample (i.e. UK, France and Germany) as they explicitly point out in page 1327.

\section{References}

Accounting Principles Board (APB) (1970) Statement 4, The Basic Concepts of Accounting Principles Underlying Financial Statements of Business Enterprises (New York: APB).

Ahmed, A. S., Morton, R. M. and Schaefer, T. F. (2000) Accounting conservatism and the valuation of accounting numbers: evidence of the Feltham Ohlson (1996) model, Journal of Accounting, Auditing and Finance, 15, pp. 271292.

Ahmed, A. S., Billings, B., Harris, M. S. and Morton, R. M. (2002) Accounting conservatism and cost of debt: an empirical test of efficient contracting, The Accounting Review, 77, pp. 867890.

Ball, R., Kothari, S. P. and Robin, A. (2000) The effect of international institutional factors on properties of accounting earnings, Journal of Accounting and Economics, 29, pp. 151.

Ball, R., Robin, A. and Wu, J. S. (2003) Incentives versus standards: properties of accounting income in four East Asian countries, and implications for acceptance of IAS, Journal of Accounting and Economics, forthcoming.

Barth, M. E. and Clinch, G. (2000) Scale effects in capital markets based accounting research. Working Paper, Stanford University, CA.

Barth, M. E. and Kallapur, S. (1996) The effects of cross sectional scale differences on regression results in empirical accounting research, Contemporary Accounting Research, 13, pp. 527567. 
Basu, S. (1997) The conservatism principle and the asymmetric timeliness of earnings, Journal of Accounting and Economics, 24, pp. 337.

Basu, S. (2001) Discussion on the asymmetric recognition of good and bad news in France, Germany and the United Kingdom, Journal of Business, Finance and Accounting, 28, pp. 13331349.

Basu, S., Hwang, L. and Jan, C. (2001) Differences in conservatism between Big Eight and non Big Eight auditors. Working Paper, City University of New York.

Beaver, W. H. and Ryan, S. G. (2000) Biases and lags in book value and their effects on the ability of the book to market ratio to predict book return on equity, Journal of Accounting Research, 38, pp. 127148.

Beaver, W. H., Lambert, R. A. and Morse, D. (1980) The information content of security prices, Journal of Accounting and Economics, 2, pp. 328.

Beaver, W. H., Lambert, R. A. and Ryan, S. G. (1987) The information content of security prices. A second look, Journal of Accounting and Economics, 9, pp. 139157.

Beaver, W. H., McAnally, M. L. and Stinson, C. H. (1997) The information content of earnings and prices: a simultaneous equations approach, Journal of Accounting and Economics, 23, pp. 5381.

Beekes, W., Pope, P. F. and Young, S. (2003) The link between earnings conservatism and board composition. Evidence from the UK. Working Paper, Lancaster University, UK.

Belkaoui, A. (1985) Accounting Theory, 2nd edn (Orlando, FL: Harcourt Brace Jovanovich).

Bernard, V. (1995) The Feltham Ohlson framework: implications for empiricists, Contemporary Accounting Research, 11, pp. 733747.

Burgstahler, D. C. and Dichev, I. D. (1997) Earnings, adaptation and equity value, The Accounting Review, 72, pp. 187215.

Chandra, U., Wasley, C. and Waymire, G. (2001) Income conservatism in the US technology sector. Working Paper, University of Rochester, NY.

Easton, P. D. and Sommers, G. (2003) Scale and the scale effect in market based accounting research, Journal of Business, Finance and Accounting, 30, pp. 2555.

Easton, P. D., Harris, T. S. and Ohlson, J. (1992) Aggregate accounting earnings can explain most of security returns, Journal of Accounting and Economics, 15, pp. 119142.

Fama, E. and McBeth, J. (1973) Risk, return, and equilibrium: empirical tests, Journal of Political Economy, 81, pp. 607636.

Feltham, G. and Ohlson, J. A. (1995) Valuation and clean surplus accounting for operating and financial activities, Contemporary Accounting Research, 11, pp. 689731.

Feltham, G. and Ohlson, J. A. (1996) Uncertainty resolution and the theory of depreciation measurement, Journal of Accounting Research, 34, pp. 209234.

Financial Accounting Standards Board (FASB) (1976) Interpretation No. 14, Reasonable Interpretation of the Amount of a Loss: an Interpretation of FASB Standard No. 5 (Norwalk, CT: FASB).

Financial Accounting Standards Board (FASB) (1980) Statement of Financial Accounting Concepts 2, Qualitative Characteristics of Accounting Information (Norwalk, CT: FASB).

Francis, J. and Schipper, K. (1999) Have financial statements lost their relevance?, Journal of Accounting Research, 37, pp. 319352.

Garrod, N. and Valentincic, A. (2001) Differential ex post conservatism effects for loss making firms in the UK. Working Paper, Glasgow University, UK.

Gigler, F. B. and Hemmer, T. (2001) Conservatism, optimal disclosure policy, and the timeliness of financial reports, The Accounting Review, 76, pp. 471493.

Giner, B. and Grambovas, C. (2001) Asymmetric timeliness of earnings and conservatism in a euro zone context. Working Paper, Universidad de Valencia, Spain. 
Giner, B. and Rees, W. (2001) On the asymmetric recognition of good and bad news in France, Germany and the United Kingdom, Journal of Business, Finance and Accounting, 28, pp. 12851331.

Givoly, D. and Hayn, C. (2000) The changing time series properties of earnings, cash flows and accruals: has financial reporting become more conservative?, Journal of Accounting and Economics, 29, pp. 287320.

Hayn, C. (1995) The information content of losses, Journal of Accounting and Economics, 20, pp. 125153.

Helbok, G. and Walker, M. (2001) On the nature and rationality of analysts' forecasts under earnings conservatism. Working Paper, University of Manchester, UK.

Holthausen, R. and Watts, R. (2001) The relevance of the value relevance literature for financial accounting standard setting, Journal of Accounting and Economics, 31,pp. 375.

Huijgen, C. and Lubberink, M. (2001a) A wealth based explanation for earnings conservatism, European Finance Review, 5, pp. 323349.

Huijgen, C. and Lubberink, M. (2001b) Liability exposure effects on earnings conservatism: the case of cross listed firms. Working Paper, Groningen University, Netherlands, and Lancaster University, UK.

Joos, P. (1997) The stock market valuation of earnings and book value across international accounting systems. Doctoral Thesis, UMI.

Joos, P. and Lang, M. (1994) The effects of accounting diversity evidence from the European Union, Journal of Accounting Research, 32, pp. 141168.

Kothari, S. P. and Zimmerman, R. (1995) Price and return models, Journal of Accounting and Economics, 20, pp. 155192.

Kothari, S. P., Lys, T., Smith, C. W. and Watts, R. L. (1988) Auditor liability and information disclosure, Journal of Accounting, Auditing and Finance, 4, pp. 307339.

LaPorta, R., Lopez de Silanes, F. and Shleifer, A. (1999) Corporate ownership around the world, Journal of Finance, 54, pp. 471517.

Leuz, C., Nanda, D. and Wysocki, P. (2003) Earnings management and investor protection: an international comparison, Journal of Financial Economics, 69, pp. 505527.

Lo, K. and Lys, T. (2000) The Ohlson model: contributions to valuation theory, limitations, and empirical applications, Journal of Accounting, Auditing and Finance, 15, pp. 337367.

Nobes, C. W. (1983) A judgemental international classification of financial reporting practices, Journal of Business, Finance and Accounting, 10, pp. 119.

Ohlson, J. A. (1995) Earnings, book values and dividends in equity valuation, Contemporary Accounting Research, 11, pp. 661687.

Pope, P. F. and Walker, M. (1999) International differences in the timeliness, conservatism and classification of earnings, Journal of Accounting Research, 37 (Supplement), pp. 5387.

Pope, P. F. and Walker, M. (2003) Ex ante and ex post accounting conservatism, asset recognition and asymmetric earnings timeliness. Working Paper, Lancaster University and University of Manchester, UK.

Raonic, I., McLeay, S. and Asimakopoulos, I. (2003) The timeliness of income recognition by interlisted European companies: an analysis of institutional and market complexity. Working Paper, University of Wales, Bangor.

Ryan, S. G. and Zarowin, P. A. (2003) Why has the contemporaneous linear returns earnings relation declined?, The Accounting Review, 78, pp. 523553.

Sivakumar, K. and Waymire, G. (2003) Enforceable accounting rules and income measurement by early 20th century railroads, Journal of Accounting Research, 41, pp. 397432 . 
Skinner, D. J. (1994) Why do firms voluntarily disclose bad news?, Journal of Accounting Research, 32, pp. 3860.

Smith, C. J. (1979) Applications of options pricing analysis, in Bicksler, J. L. (Ed.) Handbook of Financial Economics, pp. 79121 (Amsterdam: North Holland).

Smith, C. W. and Watts, R. (1992) The investment opportunity set and corporate financing, dividend, and compensation policies, Journal of Financial Economics, 32, pp. 263292.

Smith, J. M., Jr. and Skousen, F. K. (1987) Intermediate Accounting, 9th edn (Cincinnati, $\mathrm{OH}$ : South Western).

Stober, T. L. (1996) Do prices behave as if accounting book values are conservative? Cross sectional tests of the Feltham and Ohlson (1995) valuation model. Unpublished Working Paper, University of Notre Dame, IN.

Warfield, T. D. and Wild, J. J. (1992) Accounting recognition and the relevance of earnings as an explanatory variable for returns, The Accounting Review, 67, pp. 821842.

Watts, R. L. (1993) A proposal for research on conservatism. Unpublished Working Paper, University of Rochester, NY.

Watts, R. L. (2002) Conservatism in accounting. Working Paper, University of Rochester, NY.

White, H. (1980) A heteroskedasticity consistent covariance matrix estimator and a direct test for heteroskedasticity, Econometrica, 48, pp. 817838.

Zhang, X. (2000) Conservative accounting and equity valuation, Journal of Accounting and Economics, 29, pp. 125149. 